\title{
CHEMICAL AND BIOLOGICAL ALTERATIONS INDUCED BY IRRADIATION OF I'19 LABELED HUMAN SERUM ALBUMIN
}

\author{
BY ROSALYN S. YALOW AND SOLOMON A. BERSON
}

(From the Radioisotope Service, Veterans Administration Hospital, Bronx 68, N. Y.)

(Submitted for publication July 13, 1956; accepted September 14, 1956)

It has been reported (1) and confirmed (2) that $I^{131}$-labeled human serum albumin may be heterogeneous with respect to its rate of metabolism in vivo. However, some preparations appear to be homogeneous and show a constant rate of degradation equal to the slowest rate of degradation observed in the heterogeneous preparations (1). This suggests that the more rapidly degraded components of the latter represent protein fractions damaged during the iodination procedure rather than intrinsically different proteins present in the original unlabeled material (1).

The inherent sensitivity of proteins to denaturation by various chemical and physical agents encountered during manipulations in vitro in general, and in labeling procedures in particular, has been well appreciated. However, while changes in cation and anion-binding capacity, ultraviolet absorption, and amino acid composition of serum albumin following $\mathbf{x}$-irradiation have been reported (3), possible effects of self-irradiation of $I^{181}$ labeled albumin on the rate of metabolism in vivo have not been studied. Recent experience with radiation-induced alterations of insulin- $\mathrm{I}^{181}$ and the protection against such alterations offered by the presence of serum albumin (4) led to the present investigation of the effects of irradiation on albumin- ${ }^{131}$.

\section{METHODS}

Human serum albumin ${ }^{1}$ was labeled with $\mathrm{I}^{181}$ according to a method previously described (5). Appropriate amounts of carrier $\mathrm{I}^{19}$ were added so as to yield an average of less than one iodine atom per protein molecule. Four different lots of iodinated albumin were employed in the present study. After an iodination period of about five minutes the solutions were dialyzed at $4^{\circ} \mathrm{C}$ against large volumes of distilled water, with frequent changes, for about 7 hours. Three of the lots were then passed through Seitz filters into sterile vials. Aliquots of each

${ }^{1}$ Cutter albumin lot No. E 4172. This preparation revealed an $\alpha_{1}$ protein content of about 2 per cent on free electrophoresis. lot were diluted with distilled water or fortified with nonlabeled albumin as necessary to yield final protein concentrations of $200 \mu \mathrm{g}$. per $\mathrm{ml}$., $5000 \mu \mathrm{g}$. per $\mathrm{ml}$. or $50,000 \mu \mathrm{g}$. per ml. at a $\mathrm{pH}$ of 6.0 . Half of the solution at each concentration was then irradiated immediately in a General Electric $x$-ray machine, peak energy $1 \mathrm{mev}$, at a dose rate of $1500 \mathrm{rad}$ per min. for 30 minutes; the remaining half of each solution (control) was treated in an identical fashion except for the irradiation. Immediately after irradiation, sufficient non-labeled albumin was added to all control and irradiated solutions to bring protein concentrations up to $50 \mathrm{mg}$. per $\mathrm{ml}$. in order to minimize the effects of further irradiation from the self-contained $\mathrm{I}^{121.2}$ In the case of the fourth lot, the experimental solution was irradiated by $\mathrm{I}^{1 \mathrm{1}}$ added as iodide in a concentration of $2 \mathrm{mc}$. per $\mathrm{ml}$. to a solution of albumin- $\mathrm{I}^{12}$ containing $200 \mu \mathrm{g}$. per $\mathrm{ml}$. albumin. ${ }^{3}$ After almost 5 days both the experimental and control portions were again dialyzed against water until the non-precipitable radioactivity was less than 1 per cent. Non-radioactive albumin was then added to both solutions in sufficient amounts to yield final protein concentrations of $50 \mathrm{mg}$. per $\mathrm{ml}$.

Solutions were refrigerated for at least three days, while samples were checked for sterility by culture, and were then administered intravenously to hospitalized patients without proteinuria or known abnormalities of protein metabolism. Serum albumin concentrations were normal in all subjects. Blood samples were taken at frequent intervals and complete 24-hour urinary collections were made except during the first day when two collections were made. Assays of radioactivity were performed in a 5-ml. capacity well-type scintillation counter with a sensitivity of $1.00 \times 10^{\circ}$ counts per minute per $\mu \mathrm{c}$. $\mathrm{I}^{121}$ above a background of 200 counts per minute.

In addition to the albumin- $\mathrm{I}^{181}$ prepared for studies in vivo, solutions of albumin- $\mathrm{I}^{181}$ were prepared at concen-

2 The maximum irradiation received by any of these solutions from the $I^{121}$ present was calculated to be about 500 rad prior to final addition of non-labeled albumin and less than 2000 rad total before administration. Since the iodoalbumin was prepared and maintained in solutions of 5 to $10 \mathrm{ml}$. the small amount of $\beta$-particle energy dissipated outside the solution was more than compensated for by the $\gamma$-ray energy absorbed in the solution. Therefore, the factor of $120 \mathrm{gm}$. rad per $\mu \mathrm{c}$. $\mathrm{I}^{111}$ destroyed was employed in the calculations (6).

${ }^{3}$ The calculated radiation doses received by the experimental and control solutions of this lot were about $84,000 \mathrm{rad}$ and $4000 \mathrm{rad}$, respectively. 
trations of $20 \mu \mathrm{g}$. per $\mathrm{ml}$. and were subjected to $\mathrm{x}$-irradiation at dosage levels of 45 to 135 kilorad for electrophoretic analysis.

The reduction of ferricyanide ion in the presence and absence of p-chloromercuribenzoate was employed as a test for reactive sulfhydryl groups. Irradiated or control albumin solutions at initial concentrations of $200 \mu \mathrm{g}$. per $\mathrm{ml}$. were concentrated five fold by freeze-drying prior to the ferricyanide tests. The test solutions were then incubated for one hour with and without $\mathrm{p}$-chloromercuribenzoate $\left(0.16 \times 10^{-2}\right.$ molar $)$. Following the addition of potassium ferricyanide $\left(0.7 \times 10^{-3}\right.$ molar $)$ the solutions were incubated for another 15 minutes. Ferric sulfate $\left(4.0 \times 10^{-3}\right.$ molar $)$ in Duponal was then added. In the absence of p-chloromercuribenzoate the presence of freely reactive $\mathrm{SH}$ groups is evidenced by the appearance of a blue color (Prussian blue) within five minutes which reaches its maximum in about 15 minutes (early reaction). In the presence of p-chloromercuribenzoate, the color first begins to appear in about two hours (delayed reaction).

Aliquots of control and irradiated solutions were added to human plasma and subjected to electrophoresis and hydrodynamic flow on paper strips according to methods described previously (7).

\section{RESULTS}

\section{Chemical effects of irradiation}

Ten per cent cold trichloracetic acid precipitated 96 per cent to 98 per cent of radioactivity in the control solutions and 94 to 98 per cent in the $\mathrm{x}$-irradiated solutions. The more accurate technique of short run paper electrophoresis showed 3 per cent of the total radioactivity present as iodide in the irradiated solutions and less than 1 per cent in the control solutions (Figure 1). Sufficient carrier iodide ${ }^{127}$ was added prior to electrophoresis to saturate the anion binding capacity of the albumin.

Aside from the appearance of small amounts of iodide $^{131}$, detectable abnormalities were not noted on electrophoresis of the $\mathrm{x}$-irradiated solutions employed in the biologic studies. However, in the lot of albumin irradiated with $\mathrm{I}^{131}$ a small fraction of the radioactivity appeared to migrate with all the globulins. A similar phenomenon has been observed previously with irradiation damaged insulin- $\mathrm{I}^{131}(4,7)$. The absence of these migrating components in the $\mathrm{x}$-irradiated albumin- $\mathrm{I}^{131}$ solutions does not, however, indicate any qualitative difference in the effects of the two types of radiation employed, since the total radiation dose administered was almost twice as great in the lot irradiated with $\mathrm{I}^{131}$. When albumin- $\mathrm{I}^{131}$ in concen- trations of $20 \mu \mathrm{g}$. per $\mathrm{ml}$. was irradiated with $\mathrm{x}$-rays at dose levels of 45 to 135 kilorad, changes similar to those observed in the $\mathrm{I}^{131}$ irradiated solutions became readily apparent on electrophoretic analysis (Figure $2 \mathrm{a}-\mathrm{d}$ ). At the highest radiation dose level virtually all the albumin- $\mathrm{I}^{131}$ was altered and there appeared radioactive products which migrated indiscriminately with all the serum proteins. A considerably larger amount of io$\operatorname{dide}^{131}$ was also present in these solutions as was evident in short run paper electrophoresis (Figure 2e). An apparent slightly greater mobility of the albumin- ${ }^{131}$ than the stained serum albumin (Figure $2 \mathrm{a}-\mathrm{d}$ ) is an artifact introduced by the resolving time of the recording system. The peaks of radioactivity and albumin stain were found to correspond exactly when the strips were sectioned and assayed in a scintillation counter.
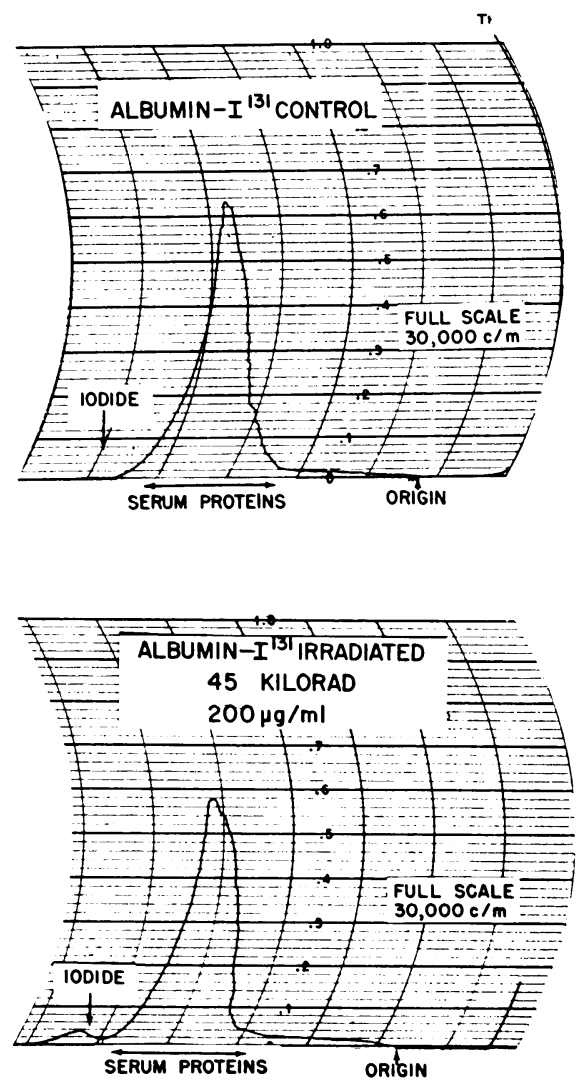

Fig. 1. Radionctivities of Paper Strips Following One and One-Half Hours of Electrophoresis Combined with Hydrodynamic Flow

Origin indicates site of application of solutions. (Phosphate buffer, ionic strength 0.1 ; constant voltage $250 \mathrm{~V}$, Whatman 3 MM paper; migration to the left.) 


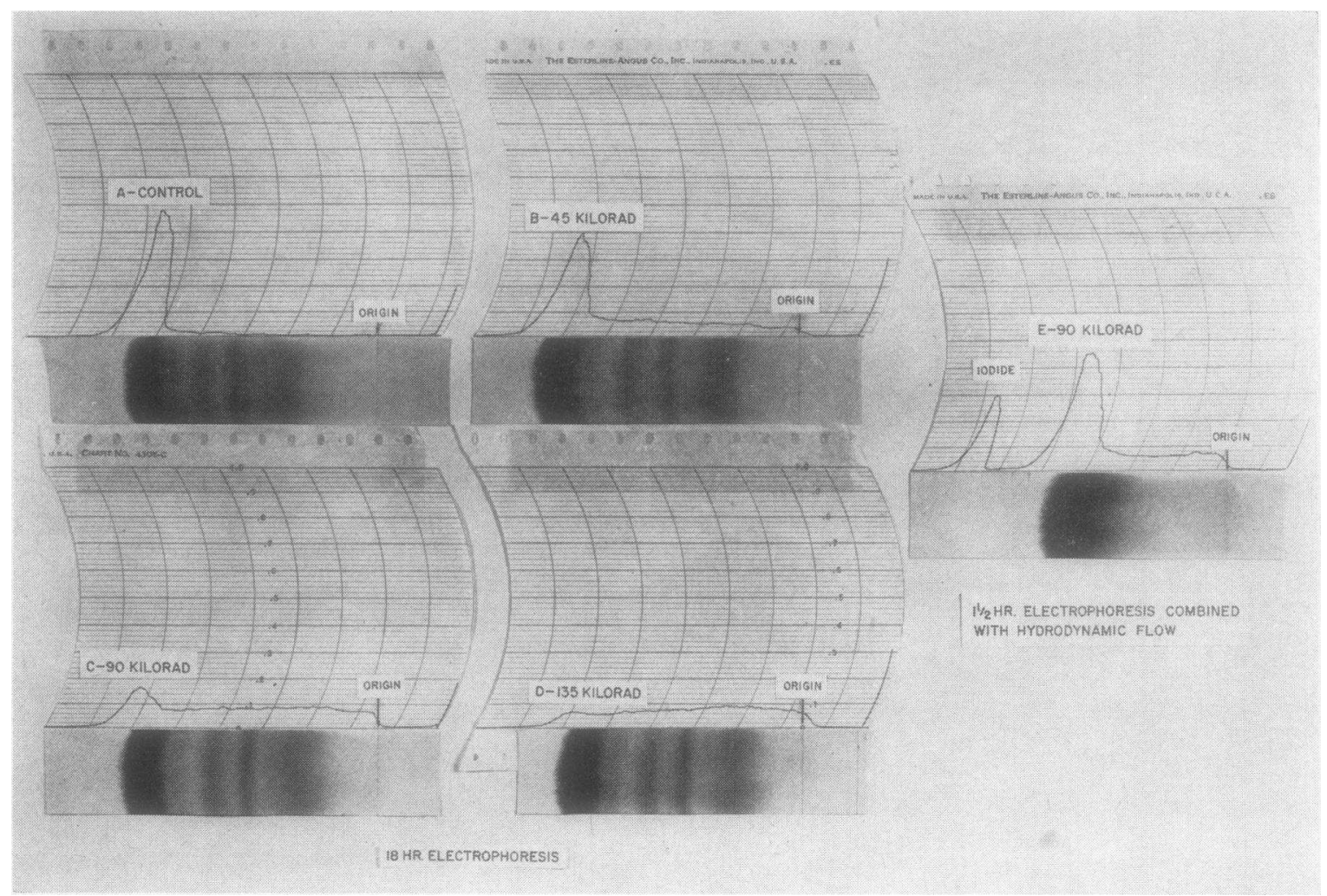

Fig. 2. Paper Strip Radioelectrophoretograms of Albumin-I ${ }^{131}$ Solutions in Plasma

Albumin- $\mathrm{I}^{131}$ solutions were subjected to irradiation doses as indicated at albumin concentrations of $20 \mu \mathrm{g}$. per $\mathrm{ml}$. Full scale reading 30,000 counts per minute on all strips.

The nature of the chemical changes accompanying these effects are not completely known. However, one important alteration, the splitting of the disulfide linkages of albumin with reduction to sulfhydryl groups, has been demonstrated by the reduction of ferricyanide in the absence but not in the presence of $\mathrm{p}$-chloromercuribenzoate (Table I). These observations have been confirmed repeatedly with non-labeled albumin as well. This radiochemical change has also been demonstrated following the irradiation of insulin and is considered in greater detail elsewhere (8).

TABLE I

Prussian Blue reaction

\begin{tabular}{lcc}
\hline & $\begin{array}{c}\text { Without } \\
\text { p-chloro- } \\
\text { mercuri- } \\
\text { benzoate }\end{array}$ & $\begin{array}{c}\text { With } \\
\text { p-chloro- } \\
\text { mercuri- } \\
\text { benzoate }\end{array}$ \\
\hline $\begin{array}{lcc}\text { Irradiated water } \\
\text { Control albumin-I }{ }^{131}\end{array}$ & 0 & 0 \\
Irradiated albumin-I & 0 & 0 \\
\hline
\end{tabular}

\section{Biologic effects of irradiation}

Following administration of solutions which received approximately $45,000 \mathrm{rad}$ from $\mathrm{x}$-rays at a concentration of $200 \mu \mathrm{g}$. albumin per ml., a large fraction of the labeled protein was degraded rapidly during the first few days, as evidenced by the excretion of large amounts of non-protein bound radioactivity in the urine (Figure 3 ) and the rapid disappearance of protein bound radioactivity from the plasma (Figure 4) in contrast to the control non-irradiated material. The rate of removal from the plasma of the moiety remaining after the first week or so was also greater with irradiated than with control solutions although there was a tendency for some of the individual curves in the former group to flatten out, indicating the presence of protein fractions less severely affected by the irradiation.

When solutions containing $5000 \mu \mathrm{g}$. protein per $\mathrm{ml}$. received 45,000 rad, alteration of the protein, as manifested by rapid degradation, was definitely 


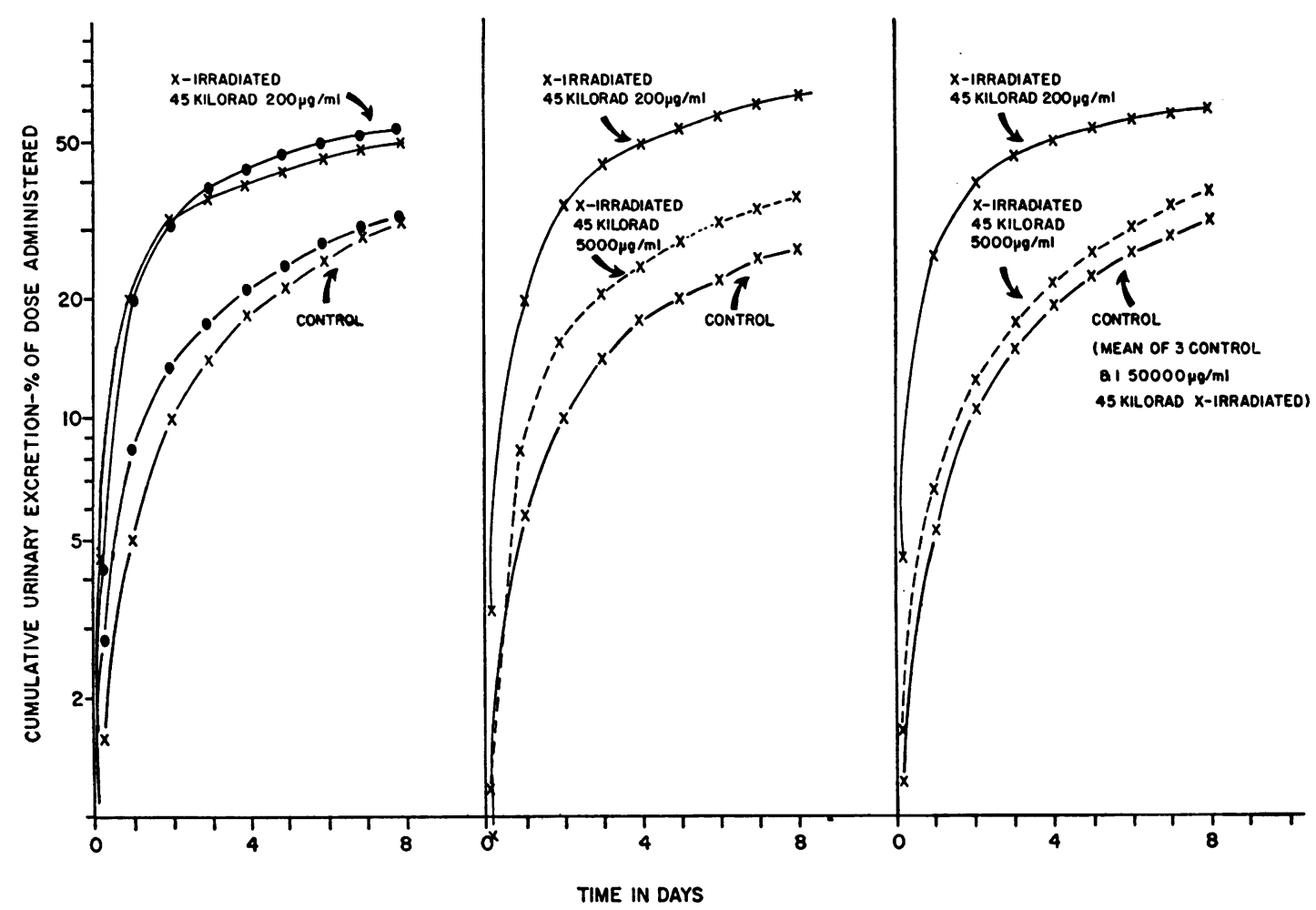

Fig. 3. Cumulative Urinary Excretion Following Intravenous Administration of Control and X-Irradiated Albumin-I ${ }^{21}$ Solutions to Normal Human Subjects

In the third frame, the curves from the three subjects receiving control albumin- $\mathrm{I}^{\text {in }}$ solutions and the one subject who had received the albumin-I ${ }^{2 m}$ irradiated at a concentration of $50 \mathrm{mg}$. per ml. were virtually indistinguishable.

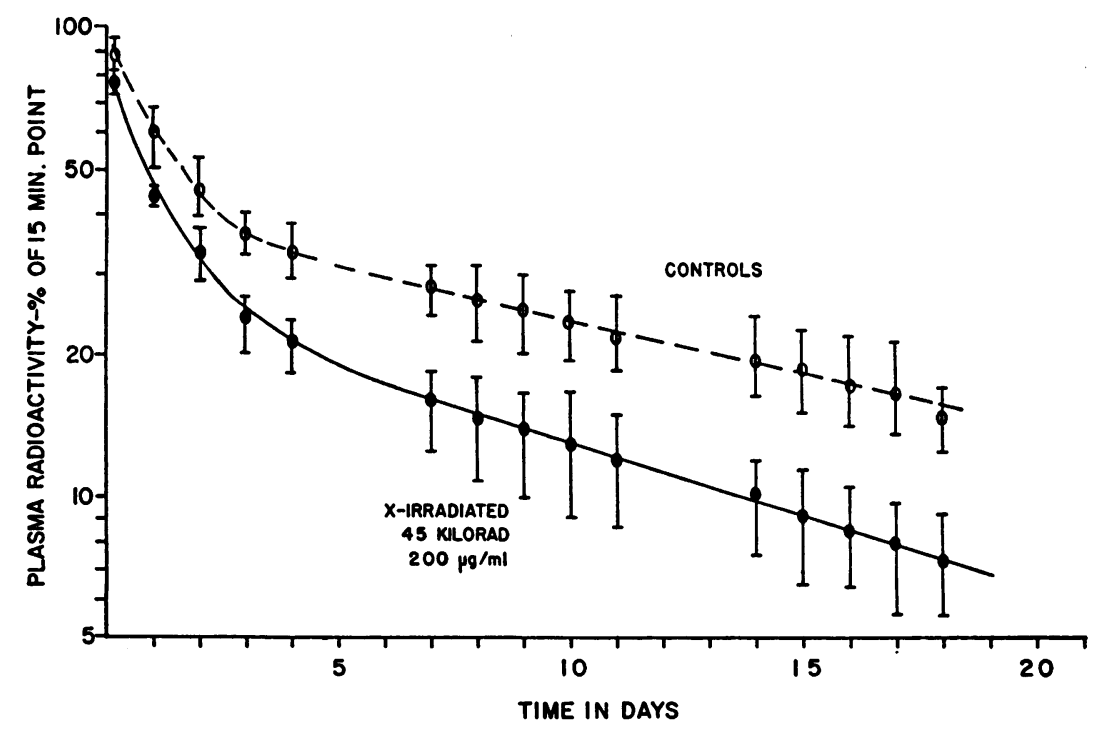

Fig. 4. Mean Plasma Concentration of Radioactivities in Six Subjects Receiving Control Albumin- $I^{21}$ and Four Subjects Receiving IrRadiated Aldumin-I ${ }^{201}$

Horizontal bars indicate extreme range of values for each point. 

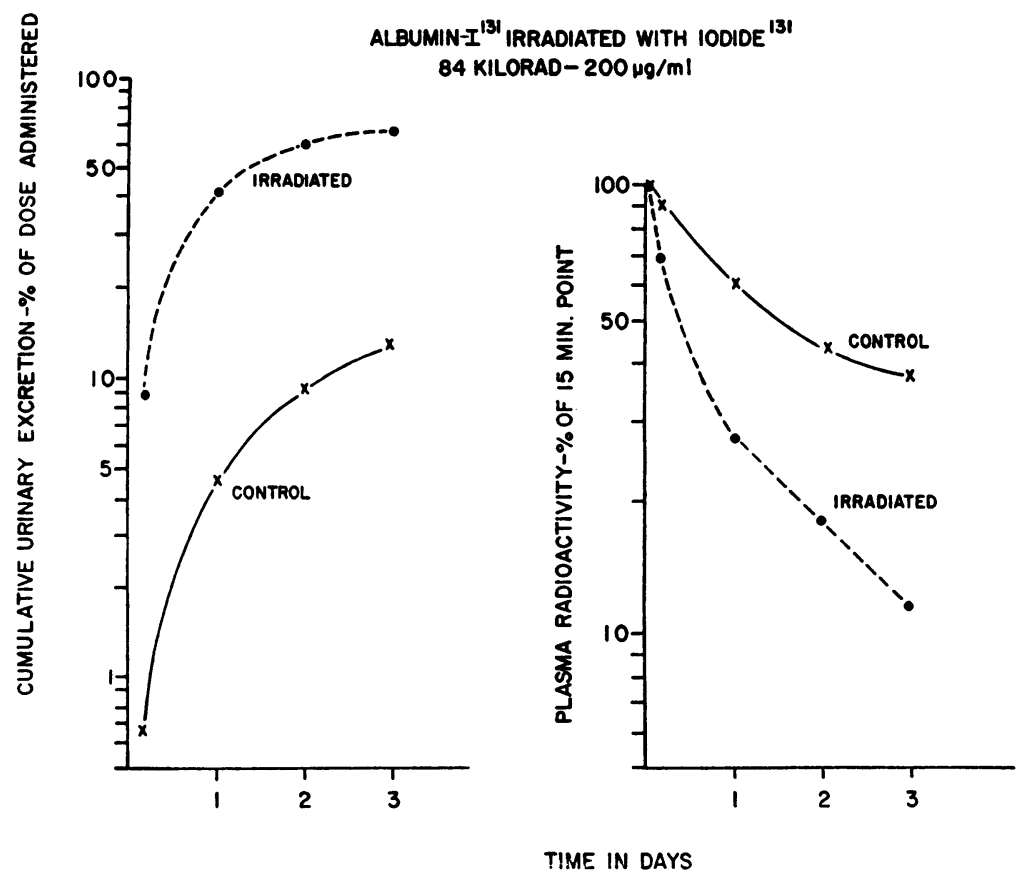

Fig. 5. Cumulative Urinary Excretion and Plasma Radioactivity Curves Following Intravenous Administration of Control and I ${ }^{131}$ IrRadiated Albumin-I ${ }^{131}$

much less striking than in the case of the more dilute solutions, but there still appeared to be a definite effect (Figure 3 ). In the single study employing a concentration of $50,000 \mu \mathrm{g}$. albumin per ml., 45,000 rad seemed to have had no detectable effect on the rate of metabolism since there was no definite difference in the excretion curve as compared to that of the three control curves with this lot of iodoalbumin (Figure 3 ). The albumin- $\mathrm{I}^{131}$ which received 84,000 rad from $\mathrm{I}^{131}$ showed the most rapid breakdown of the four lots studied (Figure 5). Some 60 per cent of the injected radioactivity appeared in the urine as protein-free $\mathrm{I}^{131}$ at the end of 48 hours compared to 9.6 per cent for the control.

\section{DISCUSSION}

The experiment in which the irradiation was delivered by a high concentration of $\mathrm{I}^{131}$ indicates that alterations occur when the protein solutions are irradiated at a slow rate as well as at the higher dose rates obtained from the $\mathrm{x}$-ray machine. The $x$-ray doses employed here $(45,000$ rad) are approximately equivalent to the radiation absorbed in one week by solutions initially con- taining $0.8 \mathrm{mc}$. $\mathrm{I}^{131}$ per $\mathrm{ml}$. $\mathrm{I}^{131}$ labeled proteins having about this concentration of radioactivity are distributed commercially and are frequently prepared by investigators in their own laboratories. When protein concentrations are high, irradiation effects may not be detectable at these dose levels. However, at low protein concentrations, even considerably smaller irradiation doses may be sufficient to produce alterations of proteins which significantly affect their biologic behavior. The absence of electrophoretic abnormalities, apart from the liberation of a small amount of iodide, in preparations which reveal strikingly altered biologic behavior, indicates the relative insensitivity of electrophoretic analysis in the detection of alterations of serum albumin. Gabrieli, Goulian, Kinersley, and Collet (9) have previously examined commercial preparations of albumin- ${ }^{131}$ by paper electrophoresis and observed considerable trailing of radioactivity behind the albumin in serum and also a lack of correspondence of peaks of radioactivity and of albumin-bound dye. Although the latter effect was not observed in the preparations employed here, the trailing observed by these authors may well have been a manifestation of irradiation damage. 
Irradiation effects in dilute protein solutions are primarily secondary in nature at the dose levels employed here. Free radicals produced as a result of the irradiation of the water are responsible for the protein alterations rather than direct ionization of the protein molecules. Thus, an increase in the concentration of the protein itself results in a decrease in the fraction of protein altered at the same irradiation dose level. In the case of some proteins, such as serum albumin, high protein concentrations may be utilized for their protective effect, since even 25 to $50 \mathrm{mg}$. may still properly be regarded as a true tracer dose for metabolic studies in man. However in the case of certain other proteins such as hormones, antigens, etc., it is often necessary to employ solutions of very high specific activity in order to permit administration of a sufficient amount of radioactivity for subsequent assay in body fluids or tissue, while at the same time restricting the amount of protein to physiologic, if not tracer, levels. Because of the high concentration of radioactivity and low concentration of protein in these cases special measures must be taken to protect against the irradiation induced damage. In such instances it has been recent practice in this laboratory to remove rapidly, by dialysis, unbound $\mathrm{I}^{131}$ from the iodoprotein solutions and to follow immediately with the addition of sufficient amounts of serum albumin to yield final protein concentrations of 50 to $100 \mathrm{mg}$. per $\mathrm{ml}$. Almost complete dialysis can be effected in a few hours if small volumes of solution $(5$ to $10 \mathrm{ml}$.) are dialyzed against frequent changes of large volumes (2 liters) of water, saline or other solutions. The added albumin serves as an unlabeled protective agent which minimizes any subsequent irradiation damage and does not interfere with the biologic action of the labeled proteins (4).

There is no intent to imply, by the studies presented here, that alteration of $\mathrm{I}^{131}$ labeled proteins induced by self-irradiation necessarily represents the major hazard to proteins during iodination procedures. Alterations in biologic behavior may be induced by overiodination (1), by chemical changes or by other factors even when irradiation effects are minimized by the use of low specific activity preparations. Variability in the rate of metabolism of albumin- ${ }^{131}$ with preparations produced by different iodinating procedures has been reported previously (1) and confirmed recently (10) ; certain methods of iodination $(1,10)$ appear to be less noxious to the proteins than others. However, the use of labeled proteins of high specific activity requires special attention to radiation induced alterations.

\section{SUMMARY}

1. Human serum albumin labeled with $I^{131}$ was irradiated at protein concentrations of $20 \mu \mathrm{g}$. per $\mathrm{ml}$. to $50 \mathrm{mg}$. per $\mathrm{ml}$. with x-rays at dosage levels of 45 to 135 kilorad and with iodide $e^{131}$ at a dosage level of 84 kilorad.

2. Biologic alteration induced by irradiation was evidenced by susceptibility to rapid metabolic degradation in vivo. This alteration was detectable when irradiation was performed with protein concentrations of $5 \mathrm{mg}$. per ml. or less and with dosages corresponding to those received in one week by solutions initially containing $0.8 \mathrm{mc}$. $\mathrm{I}^{131}$ per ml. or greater.

3. Following irradiation, the appearance of reactive sulfhydryl groups was demonstrated by reduction of ferricyanide in the absence but not in the presence of $\mathrm{p}$-chloromercuribenzoate.

4. Anomalous migration of $\mathrm{I}^{131}$ labeled fragments on paper electrophoresis and liberation of $\mathrm{I}^{131}$ as iodide were also observed following irradiation.

5. The extent of alteration induced was a direct function of the radiation dose and was inversely related to the protein concentration during irradiation.

6. The potential radiation damage to $\mathrm{I}^{131}$ labeled proteins of high specific activity is discussed and a method for protection against radiation damage is suggested.

\section{ACKNOWLEDGMENTS}

We are indebted to Melanie Knopf for the illustrations, to Frieda Steiner and Eve Spelke for secretarial assistance, and to Ralph Edison for his technical assistance.

\section{REFERENCES}

1. Berson, S. A., Yalow, R. S., Schreiber, S. S., and Post, J., Tracer experiments with $\mathrm{I}^{\mathbf{1 3 1}}$ labeled human serum albumin: Distribution and degradation studies. J. Clin. Invest., 1953, 32, 746.

2. Volwiler, W., Goldsworthy, P. D., MacMartin, M. P., Wood, P. A., Mackay, I. R., and Fremont-Smith, 
$\mathrm{K}$, Biosynthetic determination with radioactive sulfur of turn-over rates of various plasma proteins in normal and cirrhotic man. J. Clin. Invest., 1955, 34, 1126.

3. Barron, E. S. G., Ambrose, J., and Johnson, P., Studies on the mechanism of action of ionizing radiations. XIII. The effect of $x$-irradiation on some physico-chemical properties of amino acids and proteins. Radiation Research, 1955, 2, 145.

4. Yalow, R. S., and Berson, S. A., Effect of $x$-rays on trace-labeled $I^{2 m}$-insulin and its relevance to biologic studies with $\mathrm{I}^{12 \mathrm{~m}}$-labeled proteins. Radiology, 1956, 66, 106.

5. Bauman, A., Rothschild, M. A., Yalow, R. S., and Berson, S. A., Distribution and metabolism of $I^{21}$ labeled human serum albumin in congestive heart failure with and without proteinuria. J. Clin. Invest., 1955, 34, 1359.
6. Yalow, A. A., Dosimetry of therapeutic use of internally administered radioisotopes in Therapeutic Use of Artificial Radioisotopes. 1956, P. F. Hahn, Ed., New York, John Wiley \& Sons, 1956, p. 30.

7. Berson, S. A., Yalow, R. S., Bauman, A., Rothschild, M. A., and Newerly, K., Insulin-I ${ }^{221}$ metabolism in human subjects: Demonstration of insulin binding globulin in the circulation of insulin treated subjects. J. Clin. Invest., 1956, 35, 170.

8. Yalow, R. S., and Berson, S. A., Some effects of irradiation of insulin and insulin- $\mathrm{I}^{12}$. In preparation.

9. Gabrieli, E. R., Goulian, D., Jr., Kinersley, T., and Collet, R., Zone paper electrophoresis studies on radio-iodinated human serum albumin. J. Clin. Invest., 1954, 33, 136.

10. McFarlane, A. S., Labelling of plasma proteins with radioactive iodine. Biochem. J., 1956, 62, 135. 